\title{
PENGARUH PELATIHAN DAN PENGEMBANGAN KARYAWAN TERHADAP KOMPETENSI KARYAWAN PADA PDAM TIRTANADI PROVINSI SUMATERA UTARA
}

\author{
Abdurrahim \\ Alumni Jurusan Manajemen FE Universitas Negeri Medan \\ Aprinawati \\ Dosen Jurusan Manajemen FE Universitas Negeri Medan
}

\begin{abstract}
Issues raised in this study is whether there is an effect of employee training on the development of employees, effect of employee training on the competence of employees, the development of employees on the competence of employees at PDAM Tirtanadi North Sumatra either simultaneously or partial. The method used in this study is a correlational method with path analysis that aims to measure the relationship between variables. The total population in this research is 209 employees and sample taken as many as 65 employees. Samples were taken using Arikunto formula. Data analysis techniques are descriptive analysis and inferential statistical analysis. After the data were analyzed with SPSS 22.0, the path analysis obtained by the equation: $X_{2}=0.380 x_{1}+0.925 \varepsilon_{1} ; X_{3}=$ $0,296 X_{1}+0,393 X_{2}+0,818 \varepsilon 2$. Hypothesis test shows the results of path coefficient effect of employee training on the development of employees amounted to 0.380 with tcount of 3.258 at a significance level of 0.002, the effect of employee training on the competence of employees amounted to 0,296 with tcount of 2.639 at a significance level of 0.011, influence the development of employee competencies of employees amounted to 0.393 With a value of t count of 3.502 at the level of significance of 0.001. Thus this hypothesis is accepted that there are pengaru employee training to employee development, there are significant employee training on employee competencies and there is the influence employees' competence development of employees.
\end{abstract}

Keywords: Employee Training, Employee Development, Employee Competency

\section{PENDAHULUAN}

Perkembangan dan pertumbuhan perusahaan mempersyaratkan ketersediaan sumber daya manusia yang andal. Upaya menyediakan sumber daya tersebut dapat diperoleh melalui peningkatan kualitas sumber daya manusia. Sumber daya manusia yang berkualifikasi menurut kebutuhan perusahaan dapat diperoleh melalui program pelatihan dan pengembangan karyawan. Pelatihan dan pengembangan karyawan merupakan faktor yang mendorong tercapainya kompetensi karyawan sehingga dapat memberikan kinerja terbaik pada perusahaan. Perusahaan perlu mengidentifikasi kebutuhan organisasi sehingga perusahaan dapat menerapkan jenis program pelatihan dan pengembangan yang akan diberikan kepada individu dalam organisasi. Kesesuaian kebutuhan organisasi dan tugas dengan program pelatihan dan pengembangan karyawan akan mendukung peningkatan kompetensi karyawan. Tujuan peningkatan kompetensi adalah untuk mengetahui tingkat kinerja yang diharapkan oleh perusahaan dari karyawannya. Kompetensi karyawan merupakan 
sebuah karakteristik dasar seseorang. Cara berpikir, bersikap dan bertindak seorang karyawan mencerminkan kompetensi karyawan tersebut. Karakteristik tersebut dapat dipertahankan oleh seseorang pada waktu periode tertentu sehingga karyawan tersebut dianggap kompeten.

Beberapa kegiatan pelatihan dan pengembangan telah disiapkan untuk mengantisipasi rendahnya tingkat kompetensi karyawan, dijelaskan bahwa terdapat 13 Divisi yang sudah mengadakan program pelatihan dan pengembangan, dari masing masing divisi tersebut frekuensi program pertahunnya dari rentang 1-5 kali kegiatan. Manajemen PDAM Tirtanadi Provinsi Sumatera Utara memahami pentingnya ketersediaan sumber daya manusia yang kompeten. Manajemen perusahaan telah berupaya meningkatkan kompetensi karyawannya melalui program pelatihan dan pengembangan.

\section{KAJIAN PUSTAKA}

\section{Kompetensi Karyawan}

Moeheriono

mengemukakan bahwa kompetensi adalah karakteristik yang mendasari seseorang berkaitan dengan efektifitas kinerja individu dalam pekerjaaannya atau karakteristik dasar individu yang memiliki hubungan kausal atau sebagai sebab-akibat dangan kinerja yang dijadikan acuan, efektif atau kinerja prima atau superior di tempat kerja atau pada situasi tertentu. Pembentuk kompetensi berasal dari dalam diri individu ataupun melalui proses pembentukan kompentensi.

Wibowo

(2007:

88)

Kompetensi merupakan dimensi perilaku yang berada di belakang kinerja kompeten. Sering dinamakan kompetensi perilaku karena dimaksudkan untuk menjelaskan bagaimana orang berperilaku ketika mereka menjalankan perannya dengan baik.

Michael Zwell (dalam Wibowo, 2007:93) memberikan lima indikator kompetensi, yang terdiri dari task achievement, relationship, personal attribute, managerial, dan leadership.Task achievement, merupakan kategori kompetensi yang berhubungan dengan kinerja baik. Kompetensi yang berkaitan dengan task achievement ditunjukkan oleh: orientasi pada hasil, mengelola kinerja, memengaruhi, inisiatif, efisiensi produksi, fleksibilitas, inovasi, peduli pada kualitas, perbaikan berkelanjutan, dan keahlian teknis. Relationship, merupakan kategori kompetensi yang berhubungan dengan komunikasi dan bekerja baik dengan orang lain dan memuaskan kebutuhannya. Kompetensi berhubungan dengan relationship meliputi: kerja sama, orientasi pada pelayanan, kepedulian antarpribadi, kecerdasan organisasional, membangun hubungan, penyelesaian konflik, perhatian pada komunikasi dan sensitivitas lintas budaya. Personal attribute, merupakan kompetensi intrinsik individu dan menghubungkan bagaimana orang berpikir, merasa, belajar, dan berkembang. Personal attribute merupakan kompetensi yang meliputi: integritas dan kejujuran, pengembangan diri, ketegasan, kualitas keputusan, manajemen stress, berpikir analitis, dan berpikir konseptual. Managerial, merupakan 
kompetensi yang secara spesifik berkaitan dengan pengelolaan, pengawasan dan mengembangkan orang. Kompetensi manajerial berupa: memotivasi, memberdayakan, dan mengembangkan orang lain. Leadership, merupakan kompetensi yang berhubungan dengan memimpin organisasi dan orang untuk mencapai maksud, visi, dan tujuan organisasi. Kompetensi berkenaan dengan leadership meliputi: kepemimpinan visioner, berpikir strategis, orientasi kewirausahaan, manajemen perubahan, membangun komitmen organisasional, membangun fokus dan maksud, dasar-dasar, dan nilainilai

\section{Pelatihan Karyawan}

Menurut Siagian $(2011,67)$ pelatihan adalah suatu proses pendidikan jangka pendek bagi para karyawan operasional untuk memperoleh keterampilan tehnik operasional secara sistematis, sehingga dalam pelatihan lebih memerlukan tehnikal skill daripada konseptual skill. Menurut Robert $(2006 ; 56$ ) Keterampilan teknik merupakan kompetensi spesifik untuk melaksanakan tugas atau kemampuan menggunakan teknik-teknik ,alat-alat, prosedur - prosedur dan pengetahuan tentang lapangan yang dispesialisasi secara benar dan tepat dalam pelaksanaan tugasnya .

\section{Gibson}

$(2008,65)$

menggunakan 4 indikator untuk mengukur variabel pelatihan kerja yang berperan dalam meningkatkan Kemampuan Tehnik Karyawan yaitu sebagai berikut: Kemampuan karyawan untuk mengembangkan dan mengikuti rencana-rencana kebijakan dan prosedur yang efektif.Kemampuan untuk memproses tata warkat atau kertas kerja dengan baik, teratur dan tepat waktu.Kemampuan untuk mengelola pengeluaran atas suatu anggaran.Kemampuan untuk menggunakan pengetahuannya, peralatan-peralatan (tools), pengalaman (experience), dan teknis-teknis dari berbagai disiplin ilmu untuk memecahkan masalah.

\section{Pengembangan Karyawan}

$$
\text { Siagian }
$$

mendefenisikan pengembangan merupakan suatu proses pendidikan jangka panjang bagi para karyawan manajerial untuk mempe-roleh penguasaan konsep-konsep abstrak dan teoritis secara sistematis. Dalam pengembangan diperlukan banyak conceptual skills daripada technical skills.

Menurut Robert (2006;56 ) Keterampilan konseptual adalah kemampuan mengkoordinasi dan mengintergrasi semua kepentingan kepentingan dan aktifitas -aktifitas organisasi atau kemampuan mental mendapatkan ,menganalisa dan interpretasi informasi yang diterima dari berbagai sumber. Ini mencakup kemampuan melihat organisasi sebagai suatu keseluruhan ,memahami bagaimana hubungan antar unit atau bagian secara keseluruhan, memahami bagaimana bagian -bagian tergantung pada yang lain ,dan mengantisipasi bagaimana suatu perubahan dalam tiap bagian akan mempengaruhi keseluruhan. Kemampuan melihat gambaran keorganisasian secara keseluruhan dengan pengintegrasian dan pengkoordinasian sejumlah besar aktivitas - aktivitas merupakan keterampilan konseptual. Gibson $(2008,65)$ menggunakan 4 indikator untuk mengukur variabel pengembangan karyawan yang berperan dalam 
meningkatkan

Kemampuan

Konseptual Karyawan yaitu sebagai berikut: Kemampuan karyawan untuk membina dan menganalisis informasi baik dari dalam maupun dari luar lingkungan organisasi. Kemampuan untuk merefleksikan arti perubahan tersebut dalam tugas. Kemampuan untuk menentukan keputusan yang berkaitan dengan bidang tugasnya.Kemampuan untuk melakukan perubahan dalam pekerjaannya terutama yang perlu dalam organisasi.

\section{METODE PENELITIAN}

Penelitian ini dilakukan pada karyawan PDAM Tirtanadi Provinsi Sumatra Utara yang telah mengikuti program pelatihan dan pengembangan - Teknik pemilihan sampel dalam penelitian ini menggunakan simple random sampling (sampel acak sederhana).Dalam penelitian ini diambil sampel sebanyak $30 \%$ dari 209 karyawan yang sudah mengikuti kegiatan Pelatihan dan pengembangan Karyawan yaitu sebanyak 65 Karyawan. Dalam pengujian hipotesis, yang menjadi variabel penelitian ini adalah Variabel Eksogen dalam penelitian ini adalah Pelatihan (X1). Variabel Endogen dalam penelitian ini adalah Pengembangan Karyawan (X2) dan Kompetensi Karyawan (X3).

Sebelum melakukan analisis data, terlebih dahulu dilakukan uji Validitas dan Reliabilitas, Uji validitas dan reabilitas dilakukan untuk menguji apakah kuesioner layak digunakan sebagai instrumen penelitian atau tidak. Teknik analisis data yang digunakan dalam penelitian ini adalah analisis jalur (Path
Analysis). Sedangkan Uji Hipotesis menggunakan Uji t.

\section{HASIL PENELITIAN DAN \\ PEMBAHASAN}

Uji Hipotesis

Pengujian hipotesis dilakukan dengan menggunakan analisis jalur (path analysis). Dalam penelitian ini, terdapat dua persamaan yang muncul. Kerangka hubungan antar jalur dapat dilihat melalui persamaan variable berikut :

$\mathbf{x}_{2}=\rho X_{2} x_{1} x_{1}+\varepsilon_{1}$

$\mathbf{x}_{3}=\rho X_{3} x_{1} x_{1}+\rho X_{3} x_{2} x_{2}+\varepsilon_{2}$

Untuk mengetahui koefisien jalur sub-struktural 1 dapat dilihat dari nilai Beta pada tabel dibawah ini :

Tabel 1. Coefficients Sub Struktural I

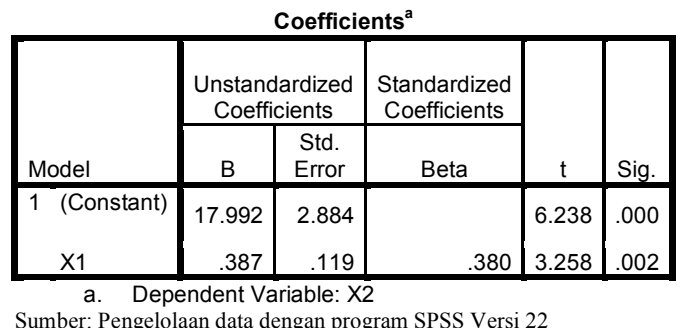

Dari tabel di atas diketahui masingmasing koefisien jalur dari setiap variable dan didapatkan persamaan sebagai berikut :

$\rho X_{2} \varepsilon_{1}=\sqrt{1-\mathrm{R}^{2}}$

Tabel 2. R Square Sub Struktural I

Model Summary
\begin{tabular}{|l|c|r|r|r|}
\hline & & $\mathrm{R}$ & $\begin{array}{c}\text { Sdjusted } \\
\mathrm{R} \\
\text { Model }\end{array}$ & $\begin{array}{c}\text { Std. } \\
\text { Error of } \\
\text { the } \\
\text { Estimate }\end{array}$ \\
\hline 1 & $.380^{\mathrm{a}}$ & .144 & .131 & 3.477 \\
\hline
\end{tabular}
a. Predictors: (Constant), X1

Diketahui $R$ Square dari perhitungan di atas sebesar 0,144

Maka $\varepsilon 1=\sqrt{1-0,144}-0,925$

Jadi

$\mathbf{x}_{2}=\rho X_{2} x_{1} x_{1}+\varepsilon_{1}$

$\mathbf{X}_{2}=0,380 x_{1}+0,925 \varepsilon_{1}$ 
Untuk mengetahui koefisien jalur sub structural II dapat dilihat dari nilai beta pada tabel di bawah ini :

Tabel 3. Coefficients Sub Struktural II Coefficients $^{a}$

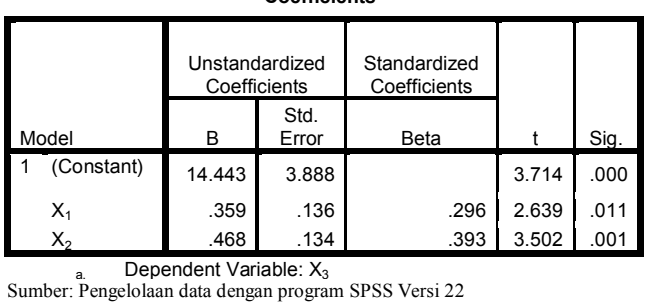

Dari tabel tersebut diketahui masingmasing koefisien jalur dari setiap variable dan didapatkan persamaan sebagai berikut :

$\rho X_{3} \varepsilon_{2}=\sqrt{1-\mathrm{R}^{2}}$

Tabel 4. R Square Sub Struktural II Model Summary

\begin{tabular}{|c|c|c|c|c|}
\hline Model & $\mathrm{R}$ & $\begin{array}{c}\mathrm{R} \\
\text { Square }\end{array}$ & $\begin{array}{c}\text { Adjusted } \\
\text { R } \\
\text { Square }\end{array}$ & $\begin{array}{c}\text { Std. } \\
\text { Error of } \\
\text { the } \\
\text { Estimate }\end{array}$ \\
\hline 1 & $575^{\mathrm{a}}$ & .331 & .309 & 3.685 \\
\hline
\end{tabular}

a. Predictors: (Constant), X2, X1

Diketahui $R$ Square senilai 0,331

Maka $\varepsilon 2=\sqrt{1-0,331}=0,818$ Jadi

$\mathbf{X}_{3}=\rho X_{3} x_{1} x_{2}+\rho X_{3} x_{2} x_{2}+\varepsilon_{2}$ $\mathbf{X}_{3}=0,296 \mathrm{x}_{1}+0,393 \mathrm{x}_{2}+0,818 \varepsilon_{2}$

\section{Analisis Data}

Dari tabel di bawah ini, dapat dilihat masing-masing pengaruh variabel. Berikut ini akan dijelaskan pengaruh masing-masing variabel.

Tabel 5. Rangkuman Hasil Coefficients Sub-Struktural I dan Sub-Struktural II

\begin{tabular}{|l|l|l|l|}
\hline Pengaruh & $\mathbf{t}_{\text {hitung }}$ & $\mathbf{t}_{\text {table }}$ & $\begin{array}{l}\text { Sig. } \\
\text { Alpha }\end{array}$ \\
\hline $\mathrm{X}_{1}->\mathrm{X}_{2}$ & 3,258 & 1.998 & 0.002 \\
\hline $\mathrm{X}_{1}->\mathrm{X}_{3}$ & 2,639 & 1.998 & 0,011 \\
\hline $\mathrm{X}_{2}->\mathrm{X}_{3}$ & 3,502 & 1.998 & 0,001 \\
\hline
\end{tabular}

Sumber: Pengolahan Data

\section{Pengaruh Pelatihan Karyawan Terhadap Pengembangan Karyawan}

Untuk melihat apakah ada pengaruh antara variabel pelatihan karyawan terhadap pengembangan karyawan, dilakukan dengan membandingkan nilai $t_{\text {tabel }}$ dengan $t_{\text {hitung. }}$ Kemudian untuk melihat apakah variabel pelatihan karyawan berkontribusi secara siginifikan atau tidak terhadap variabel pengembagan karyawan, dilakukan dengan melihat nilai probabilitas signifikansi.

Berdasarkan tabel 4.25 nilai thitung variabel $X_{1}$ terhdap $X_{2}$ sebesar 3,258. Artinya $t_{\text {hitung }}>t_{\text {tabel }}(3,258>1,998)$. Dengan demikian, dapat disimpulkan bahwa variabel $X_{1}$ berpengaruh terhadap variabel $X_{2}$. Variabel $X_{1}$ mempunyai nilai signifikansi lebih kecil dari nilai $\alpha(0,002<0,05)$ dan besarnya beta variabel $\mathrm{X}_{1}$ berkontribusi secara signifikan terhadap variabel $X_{2}$. Maka dapat disimpulkan bahwa pelatihan karyawan berpengaruh signifikan terhadap pengembangan karyawan sebesar $38 \%$.

\section{Pengaruh Pelatihan Karyawan Terhadap Kompetensi Karyawan}

Untuk melihat apakah ada pengaruh antara variabel pelatihan karyawan terhadap kompetensi karyawan, dilakukan dengan membandingkan nilai $t_{\text {tabel }}$ dengan $t_{\text {hitung. }}$ Kemudian untuk melihat apakah variabel pelatihan karyawan berkontribusi secara siginifikan atau tidak terhadap variabel kompetensi karyawan, dilakukan dengan melihat nilai probabilitas signifikansi.

Berdasarkan tabel 4.25 nilai $t_{\text {hitung }}$ variabel $\mathrm{X}_{1}$ terhadap $\mathrm{X}_{3}$ sebesar 2,639 . Artinya $t_{\text {hitung }}>t_{\text {tabel }}(2,369>$ 
1,998). Dengan demikian, dapat disimpulkan bahwa variabel $\mathrm{X}_{1}$ berpengaruh terhadap variabel $\mathrm{X}_{3}$. Variabel $X_{1}$ mempunyai nilai signifikansi lebih kecil dari nilai $\alpha$ $(0,011<0,05)$ dan besarnya beta variabel $\mathrm{X}_{1}$ berkontribusi secara signifikan terhadap variabel $\mathrm{X}_{3}$. Maka dapat disimpulkan bahwa pelatihan karyawan berpengaruh signifikan terhadap kompetensi karyawan sebesar $29 \%$.

\section{Pengaruh Pengembangan Karyawan Terhadap Kompetensi Karyawan}

Untuk melihat apakah ada pengaruh antara variabel pengembangan karyawan terhadap kompetensi karyawan, dilakukan dengan membandingkan nilai $t_{\text {tabel }}$ dengan $t_{\text {hitung. Kemudian untuk }}$ melihat apakah variabel pengembangan karyawan berkontribusi secara siginifikan atau tidak terhadap variabel kompetensi karyawan, dilakukan dengan melihat nilai probabilitas signifikansi.

Berdasarkan tabel 4.25 nilai $t_{\text {hitung }}$ variabel $X_{2}$ terhadap $X_{3}$ sebesar 3,502 . Artinya $t_{\text {hitung }}>t_{\text {tabel }}(3,502>$ 1,998). Dengan demikian, dapat disimpulkan bahwa variabel $\mathrm{X}_{2}$ berpengaruh terhadap variabel $X_{3}$. Variabel $\mathrm{X}_{1}$ mempunyai nilai signifikansi lebih kecil dari nilai $\alpha$ $(0,001<0,05)$ dan besarnya beta variabel $\mathrm{X}_{2}$ berkontribusi secara signifikan terhadap variabel $\mathrm{X}_{3}$. Maka dapat disimpulkan bahwa pengembangan karyawan berpengaruh signifikan terhadap kompetensi karyawan sebesar 39\%.

\section{Diagram Jalur}

Berdasarkan penjelasan di atas maka diagram jalur dari hasil model analisis yang digunakan adalah sebagai berikut :

$\mathrm{X}_{1}$ : Pelatihan Karyawan

$\mathrm{X}_{2}$ : Pengembangan Karyawan

$\mathrm{X}_{3}$ : Kompetensi Karyawan

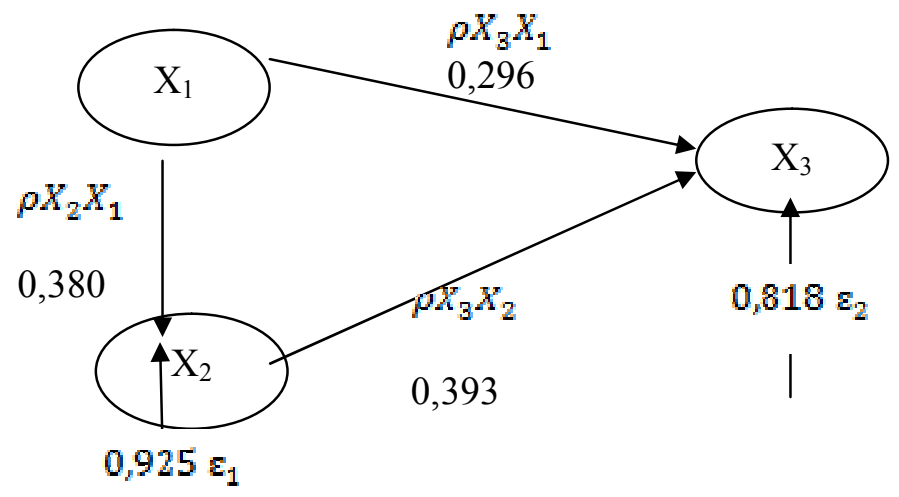

Gambar 1. Diagram Jalur Persamaa Struktural

Berdasarkan diagram jalur di atas, dapat ditentukan besarnya koefisien pengaruh langsung, pengaruh tidak langung dan pengaruh antar variabel. Besarnya pengaruh langsung secara propersional dapat dijabarkan sebagai berikut :

1. Pengaruh Pelatihan Karyawan $\left(\mathrm{X}_{1}\right)$ terhadap Pengembangan Karyawan $\left(\mathrm{X}_{2}\right)$ adalah sebesar 0,380 atau sebesar $38 \%$. 
2. Pengaruh Pelatihan Karyawan $\left(\mathrm{X}_{1}\right)$ terhadap Kompetensi Karyawan $\left(\mathrm{X}_{3}\right)$ adalah adalah 0,296 atau sebesar $29 \%$.

3. Pengaruh Pengembangan Karyawam $\left(\mathrm{X}_{2}\right)$ terhadap Kompetensi Karyawan adalah 0,393 atau sebesar 39\%.

Tabel 6. Koefisien Jalur SubStruktural I dan Sub-Struktural II

\begin{tabular}{|c|c|c|c|}
\hline \multirow{2}{*}{ Variabel } & \multicolumn{3}{|c|}{ Pengaruh } \\
\cline { 2 - 4 } & Langsung & $\begin{array}{c}\text { Tidak } \\
\text { Langsung } \\
\text { (X2) }\end{array}$ & $\begin{array}{c}\text { Total } \\
\text { Pengaruh } \\
\text { tidak } \\
\text { langsung }\end{array}$ \\
\hline $\mathrm{X} 1->\mathrm{X} 2$ & 0,380 & - & 0,38 \\
\hline $\mathrm{X} 1->\mathrm{X} 3$ & 0,29 & 0,14 & 0,43 \\
\hline $\mathrm{X} 2->\mathrm{X} 3$ & 0,39 & - & 0,39 \\
\hline
\end{tabular}

\section{Pengaruh Pelatihan Karyawan terhadap Pengembangan Karyawan}

Berdasarkan hasil analisis yang diperoleh bahwa pengujian hipotesis pelatihan karyawan terhadap pengembangan karyawan menghasilkan $t_{\text {hitung }}>t_{\text {tabel }}(3,258>$ $1,998)$ dengan signifikansi $(0,002<$ $0,05)$. Selain itu, hasil penelitian menunjukkan nilai koefisien jalur pelatihan karyawan terhadap pengembangan karyawan 0,380 . Pada taraf signifikansi 0,05 pelatihan karyawan memiliki pengaruh positif dan signifikan terhadap pengembangan karyawan sebesar $38 \%$.

Hal ini mengidentifikasin bahwa pelatihan karyawan berpengaruh positif terhadap pengembangan karyawan. Oleh karena itu, hipotesis dalam penelitian ini diterima karena pelatihan karyawan memiliki peranan penting terhadap pengembangan karyawan. Artinya pelatihan karyawan yang dilaksanakan dengan baik dan konsisten dapat meningkatkan produktivitas, efisiensi dan efektivitas seorang karyawan. Sehingga karyawan mampu mengembangkan dirinya berdasarkan kemampuan yang dimilikinya.

Implementasi untuk perusahaan sebaiknya memilih instruktur dalam pelatihan yang berkualitas untuk menumbuhkan dan meningkatkan perkembangan karyawan. Pelatihan kerja dapat dilakukan dengan pemilihan intstuktur yang kompeten dari lembaga yang terpercaya. Hal ini akan menyebabkan karyawan bersemangat mengikuti pelatihan sehingga setelah mengikuti pelatihan karyawan mampu mengembangkan pekerjaannya, Khusus nya bagi karyawan operasional yang sangat dituntut berkembangan dari waktu-kewaktu sesuai dengan kebutuhan air masyarakat yang semakin meningkat.

\section{Pengaruh Pelatihan Kerja terhadap Kompetensi Karyawan.}

Berdasarkan hasil analisis yang diperoleh bahwa pengujian hipotesis pelatihan karyawan terhadap kompetensi karyawan menghasilkan $t_{\text {hitung }}>t_{\text {tabel }}(2,369>1,998)$ dengan signifikansi $(0,011<0,05)$. Selain itu, hasil penelitian menunjukkan nilai koefisien jalur pelatihan karyawan terhadap kompetensi karyawan 0,296. Pada taraf signifikansi 0,05 pelatihan karyawan memiliki pengaruh positif dan signifikan terhadap kompetensi karyawan.

Hal ini mengidentifikasin bahwa pelatihan karyawan berpengaruh positif terhadap kompetensi karyawan. Oleh karena itu, hipotesis dalam penelitian ini 
diterima karena pelatihan karyawan memiliki peranan penting terhadap kompetensi karyawan. Artinya pelatihan karyawan yang dilaksanakan dengan baik dan konsisten dapat meningkatkan kompetensi yang sehat diantara karyawan.

Implementasi untuk perusahaan sebaiknya memilih instruktur dalam pelatihan yang berkualitas untuk menumbuhkan dan meningkatkan kemampuan karyawan. Pelatihan keryawan dapat dilakukan secara bertahap dan sesuai dengan kebutuhan karyawan. Hal ini akan menyebabkan kebutuhan karyawan sesuai dengan kegiatan pelatihan yang dilaksanakan sehingga setelah mengikuti pelatihan karyawan dapat meningkatkan kompetensi diantara karyawan.

\section{Pengaruh Pengembangan Karyawan terhadap Kompetensi Karyawan.}

Berdasarkan hasil analisis yang diperoleh bahwa pengujian hipotesis pengembangan karyawan terhadap kompetensi karyawan menghasilkan $t_{\text {hitung }}>t_{\text {tabel }}(3,502>$ 1,998) dengan signifikansi $(0,001<$ $0,05)$. Selain itu, hasil penelitian menunjukkan nilai koefisien jalur pengembangan karyawan terhadap kompetensi karyawan 0,393. Pada taraf signifikansi 0,05 pengembangan karyawan memiliki pengaruh positif dan signifikan terhadap kompetensi karyawan.

Hal ini mengidentifikasin bahwa pengembangan karyawan berpengaruh postif terhadap kompetensi karyawan. Oleh karena itu, hipotesis dalam penelitian ini diterima karena pengembangan karyawan memiliki peranan penting terhadap kompetensi karyawan. Artinya pengembangan karyawan yang dilaksanakan dengan baik dan konsisten dapat meningkatkan kompetensi yang sehat diantara karyawan.

Implementasi untuk perusahaan sebaiknya mampu memberikan kemudahan bagi karyawan dalam mengembangkan diri seperti memfasilitasi promosi jabatan secara adil kepada karyawan yang telah bekerja sesuai dengan aturan, disiplin dan memiliki prestasi di perusahaan. Sehingga semua karyawan akan merasa terdorong untuk mengembangkan diri lalu berkompetensi dengan sehat. Hal itu tentu akan berpengaruh baik untuk perusahaan.

\section{PENUTUP}

\section{Kesimpulan}

Berdasarkan hasil penelitian dan pembahasan, maka terdapat beberapa kesimpulan sebagai berikut : Hasil penelitian menunjukkan bahwa pelatihan karyawan berpengaruh positif terhadap pengembangan karyawan dengan nilai koefisien jalur sebesar $38 \%$. Hasil penelitian menunjukkan bahwa pelatihan karyawan berpengaruh positif terhadap kompetensi karyawan dengan nilai koefisien jalur sebesar $29 \%$. Hasil penelitian menunjukkan bahwa pengembangan karyawan berpengaruh positif terhadap kompetensi karyawan dengan nilai koefisien jalur sebesar 38\%. Hasil penelitian menunjukkan bahwa pengembangan karyawan memiliki pengaruh dominan terhadap kompetensi karywan yaitu 39\% 
dibandingkan dengan pelatihan karyawan sebesar $38 \%$.

\section{Saran}

Berdasarkan penelitian yang telah dilaksanakan, maka penulis mengemukakan beberapa saran sebagai berikut : Bagi PDAM Tirtanadi Provinsi Sumatera Utara.PDAM Tirtanadi seharusnya lebih memperhatikan lagi kebutuhan pelatihan dan waktu-waktu pelaksanan kegiatan pelatihan karyawan terutaman karyawan bagian operasional agar kompetensi karyawannya bisa terus meningkat. Ini dibuktikan dengan hasil penelitian dimana variabel pelatihan mempunyai pengarus terhadap kompetensi karyawan.PDAM Tirtanadi Harusnya lebih meningkatkan lagi berbagai kegiatan didalam pengembangan karyawan yang mencangkup peningkatan kemampuan konseptual karyawan agar kompetensi karyawan dapat terus dipertahankan. Ini dibuktikan dengan hasil peleitian dimana variabel pengembangan karyawan memiliki pengaruh paling besar dalam meningkatkan kompetensi karyawan.PDAM Tirtanadi Provinsi Sumatera Utara sebaiknya terus mempertahankan dan memperbaiki kompetensi karyawan dengan lebih memperhatikan intensitas dan waktu pelaksanaan pelatihan dan pengembangan sehingga karyawan yang bermasalah tingkat kompetensinya dapat lebih baik lagi. Bagi Peneliti Selanjutnya. Peneliti selanjutnya disarankan menambah Variabel lain yang mempengaruhi kompetensi karyawan karena Variabel pelatihan dan pengembangan baru mempengaruhi sekitar $77 \%$ kompetensi karyawan, sisanya dipengaruhi Variabel lain seperti keyakinan, keterampilan, pengalaman kerja, karateristik kepribadian, motivasi, isu emosional dan kemampuan intelektual.

\section{DAFTAR PUSTAKA}

A.A Anwar Prabu Mangkunegara. 2012. Sumber Daya Manusia Perusahaan. Cetakan Kesembilan Bandung. PT. Remaja Rosdakarya.

Arikunto, Suharsimi.2013. Prosedur Penelitian. Jakarta: PT Rineka Cipta

Fahmi. 2010. Pengembangan Karir Karyawan. Bandung. http://fahmiiamii10.blogspot.c om/diunduh pada 17 Mei 2017.

Ghozali, Imam. 2011. Aplikasi Analisis Multivariat dengan Program SPSS. Badan Penerbit Universitas Diponegoro: Semarang.

Gibson. 2008. Manajemen Sumber Daya Manusia, Edisi Keempat, Erlangga, Jakarta.

Handoko, T. Hani, 2012, Manajemen Personalia dan Sumber Daya Manusia. Yogyakarta : Edisi 2 BPFE.

Http://pdamtirtanadi.co.id/?page $\mathrm{id}=7$ 4/ diunduh pada 17 MEI 2017.

Http://medansatu.com/berita/17068/la pk-sebut-setahun-kinerjadireksi-pdam- tirtanadimenyebalkan-kok-bisa3/diunduh pada 17 MEI 2017.

Http://medansatu.com/berita/17087/in i-keluhan-warga-menteng-airpdam-t irtandi-macet-4-bulantapi-tagihan-membengkaklho/diunduh pada 17 MEI 2017. 
JURNAL PLANS

Penelitian Ilmu Manajemen \& Bisnis

ISSN: $1978-7057$

E-ISSN: 2527-306X

Johan Soeprihanto, 2009, Manajemen, Edisi Sembilan, Salemba Empat, Jakarta

Katz, Daniel \& Kahn, Robert L. 2006.

The Social Psychology of Organizations.

Dalam Becker \& Neuhauser The Efficient Organizations. New York.

Elsevier.

Kadarisman, M. (2013). Manajemen Pengembangan Sumber Daya Manusia. Jakarta : Rajawali Pers.

Kirkpatrick, Donald L (2006), Evaluating Training Programs-Second Edition, Berrett Kohler Publisher Inc, San Fransisco.

Mangkunegara, A. A. Anwarprabu. 2005. Evaluasi Kinerja SDM. Bandung : PT.

Refika Aditama.

Mathis, Robert L Dan Jackson, John H. (2006). Manajemen Sumber Daya Manusia.Jakarta: Salemba empat.

Triyharianto, Heru.2014. Pengaruh Pelatihan dan Motivasi Kerja Terhadap Pengembangan Karir Awak Kapal Pengawas Perikanan pada Ditjen Pengawasan Sumber Daya Kelautan dan Perikanan (PSDKP). Jurnal Manajemen Perikanan dan Kelautan Vol. 1 No. 1, 2014, artikel 4. Program Pascasarjana Universitas Terbuka

Maya Rachmatika, sany. 2015. "pengaruh evaluasi pelatihan dan pengembangan karir terhadap kinerja pegawai negeri sipil kota yogyakarta".skipsi.

Universitas

Yogyakarta.

Moeheriono. 2009. Pengukuran Kinerja Berbasis Kompetensi. Bogor: Ghalia Indonesia. .(2010), Pengukuran Kinerja Berbasis Kompetensi, Cetakan kedua, Jakarta: Ghalia Indonesia.

Nawawi, Hadari. 2008.Manajemen Sumber daya Manusia untuk Bisinis yang Kompetitif. Yogyakarta: University Press.

Non, Ayu Salamah Ninin.2012. "Pengaruh program pelatihan dan pengembangan karyawan terhadap kompetensi karyawan pada pt. Muba electric power sekayu”. Jurnal ekonomi dan informasi akuntansi (JENIUS).Vol 2 No 3sept 2012. Universitas PGRI Palembang.

Rahmadhani, Reni.2014. "Pengaruh pelatihan, pengembangan dan pengalaman kerja

terhadap kompetensi guru". Jurnal Ilmu \& Riset Manajemen Vol. 3 No. 6 (2014). Sekolah Tinggi Ilmu Ekonomi Indonesia (STIESIA) Surabaya.

Riduan dan Engkos Achmad Kuncoro. 2007 . Cara Memakai dan Menggunakan Analisis Jalur (Path Analysis). Bandung:Alfabeta

Rivai, Veithzal. (2009). Manajemen Sumber Daya Manusia untuk Perusahaan Dari TeoriKe Praktik. Jakarta: Raja Grafindo Perkasa.

Siagian, Sondang P. (2011). Manajemen Sumber Daya 
JURNAL PLANS

Penelitian Ilmu Manajemen \& Bisnis

ISSN: $1978-7057$

E-ISSN: 2527-306X

Manusia. Jakarta : Bumi

Aksara.

Saydam, Gouzali. (2011). Manajemen

Sumber Daya Manusia

(Human Resource

Management: Suatu

Pendekatan Mikro (Dalam

Tanya Jawab). Cetakan

Kedua. Jakarta: Penerbit

Dijambatan.

Simamora, Henry. 2006, Manajemen

Sumber Daya Manusia. Edisi

keempat, Yogyakarta :

STIE YKPN.

Sudarmanto SIP, MSi, 2009, Kinerja

Pengembangan Kompetensi

SDM, Cetakan

Pertama, Pustaka Pelajar,

Yogyakarta.

Sugiyono, Prof. Dr. 2007. Statistika

Untuk Penelitian. Penerbit

Alfabeta: Bandung.

Sutrisno, Edi. 2012. Manajemen Sumber Daya Manusia. Penerbit Kencana Jakarta.

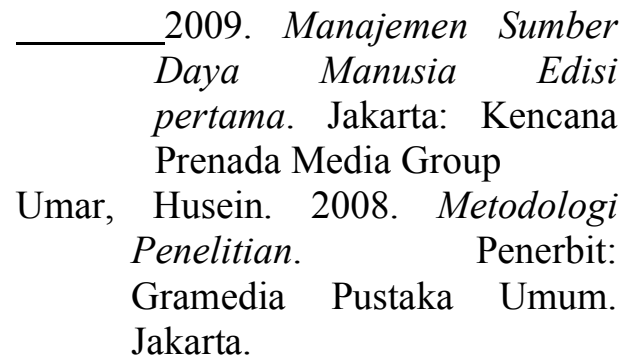

Veithzal Rivai, 2008, Manajemen Sumber Daya Manusia untuk Perusahaan, Bandung: PT. Remaja Rosda Karya.

Wahyuni, indah.2013. "Pengaruh pelatihan dan pengembangan terhadap kinerja karyawan pusat pengembangan sumber daya manusia aparatur perhubungan bogor". Skipsi Sekolah Tinggi Ilmu Ekonomi Ahmad Dahlan Jakarta.

Wibowo. 2007. Manajemen Kinerja. Jakarta : Raja Grafindo Persada. 